Though the problem differs considerably from one country to another, it may be illustrated from Greece. Out of 1,007,000 farms, only 1,033 exceed 50 hectares (125 acres), whereas 860,304 are less than 5 hectares ( $12 \cdot 5$ acres). There, rather more than half the land belongs to the farmers, rather less than half to the State, monasteries or $a_{b}$ small number of landlords, "whose interest in agriculture is slight or nonexistent". Progress in consolidation varies greatly. As the report from Spain says, "the problem has been a matter for discussion for more than 100 years" ; despite the urgent necessity, no order was made until December 20, 1952. Now, schemes can be started there eithor officially or at the request of at least 60 per cent of the farmers affected. It is interesting to note that even in the short time since the passing of the order, 257 villages covering 385,000 hectares and affecting 40,000 farmers have applied. Although France is not so badly affected, a law of March 9, 1941, had led by October 1954 to 4,910 schemes affecting $3,600,000$ hectares out of a total of 50,500,000 of the agricultural area of the country. In general, it would seem that with varying speed the needed agricultural revolution is taking place. But it would also seem that the owner-occupier smallholding is being made the ideal ; peasant-proprietors are replacing landlord and tenant. Consolidation into large holdings of several hundred acres, which technologists claim as the most efficient economically, remains almost unknown. L. DUdLEY STAMP

\title{
SIZE DIFFERENCES IN CUCURBITA
}

CIZE differences have been studied by $\mathrm{K}$. E. von $S$ Maltzahn (Canad. J. Bot., 35, 809, 831; 1957) in vegetative organs of two pure-bred strains of Cucurbita pepo L. which differ greatly in size by their genotype. The growth pattern of plants of the selected strains was found to be essentially the same in the two types. The two strains exhibited great differences in mature organ size, but only small differences in number of organs. No correlation was found between embryo size and mature size. In the early stages of primary shoot development, however, a correlation was found between embryo size and the rate of initiation of new organs. This correlation disappeared during the later stages of plant development. The parental strains had similar rates of organ formation, while the crosses showed hybrid vigour with respect to rate of new organ formation. Sizes of the apical meristems and organ primordia were essentially the same in the large and small strains and did not appear to determine mature organ size differences.

Development of size differences between the same organs of the two strains and the crosses was found to be mainly due to duration of organ growth. Rates of organ growth differed only slightly between the strains. Increase in size of successively formed organs of the same strain was also found to be mainly due to duration rather than to rate of organ growth. Mature organ size has been analysed for the two strains on the histological and cellular levels with particular emphasis on mature internode size. Differences between the strains in tissue and cell size were observed for the main tissue and cell types. Differences in internode length were determined both by differences in cell size and cell numbers. Cambial activity as expressed in numbers of radial immature derivatives and in number of divisions in the interfascicular regions was found to be much greater in strain $C F$ than in $S R C$.

No important differences were found between the large and small strain in the size of the meristematic and submeristematic regions. Early internode growth in terms of cell division and cell enlargement was also found to be similar in the two strains. It is concluded that the cellular differences found in the mature organ must be due to a longer duration of growth mainly in terms of cell enlargement but also in terms of cell division. This conclusion is supported by the results obtained on internode growth described in a previous paper. Grafting experiments with apical buds of the two strains did not show any influence of the stock on the scion; mature organ size was determined only by the scion.

\section{THE SEA OTTER}

$\mathrm{A}^{\mathrm{N}}$ $\mathrm{N}$ account of the sea otter has been given by Karl W. Kenyon of the United States Fish and Wild Life Service (Oryx, 4, No. 3 ; November 1957). In general form the sea otter, Enhydra lutris, resembles the weasel and river otter, but is larger in size. The male attains a weight of 85 pounds, the female about 65 pounds; the young at birth weigh 3-5 pounds. It is peculiar among members of its family, the Mustelidae, in having deserted dry land and fresh-water to take up a marine life. Among marine mammals it is peculiar in its adaptation to the sea. It does not possess an insulating layer of blubber but is protected from the chill of the North Pacific waters by a blanket of air trapped among the fine and closely packed fibres of its inch-long, delicate fur. Unlike the river otter and fur seal, the sea otter has but little protective coating of guard hair. The fine guard hairs present add to its beauty but do not offer much protection to the under-fur. Unlike other marine mammals, the sea otter has never taken to the open sea. It usually feeds in shallow water from 5 to $50 \mathrm{ft}$. in depth. Its food consists primarily of such sedentary forms as sea urchins, rock oysters, mussels, a variety of snail-like molluses and, in California, abalones. Occasionally fish and octopus are eaten.

Although the sea otter is not ideally adapted to its marine environment, it is far more at ease in the water than ashore. The flipper-like hind feet are clumsy on land and the long flexible body is poorly suited to walking. When otters haul out to sleep or preen, they seldom venture more than a few feet from the water.

Otters come ashore in greatest numbers when storm waves make food-diving difficult. When the weather is calm they usually sleep on the surface of the sea, simply pulling a strand of kelp over their bodies, resting the head on the chest and placing their forepaws over their eyes.

In the Aleutian Islands at least, the breeding season of the sea otter is not well defined. Most pups are 